\title{
First report of schistosomiasis on Serrambi beach, Ipojuca, State of Pernambuco
}

\author{
Verônica Santos Barbosa ${ }^{[1]}$, Ricardo José de Paula Souza e Guimarães ${ }^{[2]}$, \\ Rodrigo Moraes Loyo ${ }^{[1]}$, Silas Marcelino ${ }^{[1]}$ \\ and Constança Simões Barbosa ${ }^{[1]}$
}

[1]. Centro de Pesquisas Aggeu Magalhães, Fundação Oswaldo Cruz, Recife, Pernambuco, Brasil. [2]. Instituto Evandro Chagas, Secretaria de Vigilância Sanitária, Ministério da Saúde, Ananindeua, Pará, Brasil.

\begin{abstract}
Introduction: The expansion of schistosomiasis to previously unaffected areas is being monitored by identifying new cases and georeferencing outbreaks of vector snails. Methods: In 2014, the Laboratório de Esquistossomose began an epidemiological survey in Serrambi and registered 2,574 people living there. Results: Of these subjects, 1,414 (54.9\%) underwent feces examination and $63(4.5 \%)$ were diagnosed with Schistosoma mansoni infection. At this locality, seven breeding sites each were identified for Biomphalaria straminea and Biomphalaria glabrata. At two sites, B. glabrata were shedding cercariae. Conclusions: Implementing preventive measures is necessary to avoid the establishment of schistosomiasis in yet another tourist locality, Pernambuco.
\end{abstract}

Keywords: Schistosomiasis. Epidemiological survey. Pernambuco.

The first report of coastal transmission of schistosomiasis in the State of Pernambuco dates back to 1990. During that time, four medical students presented acute clinical form of the disease after accidental exposure via rainwater puddles on the streets of Forte Orange beach in Itamaracá Island, which had numerous Biomphalaria glabrata snails infected with the parasite Schistosoma mansoni ${ }^{(1)}$.

Over the subsequent years, other human cases and foci of intermediate snail hosts were recorded in various coastal tourist localities in this state: Porto de Galinhas, in the municipality of Ipojuca ${ }^{(2)(3)(4)(5)}$; Carne de Vaca and Ponta de Pedras in Goiana $^{(3)(6)(7)}$; Piedade, in Jaboatão dos Guararapes ${ }^{(8)}$; Janga and Pau Amarelo, in Paulista; and Mangue Seco, in Igarassu ${ }^{(3)}$.

The expansion of schistosomiasis to these previously unaffected areas is being monitored by identifying and treating new patients and by georeferencing and epidemiologically characterizing the locations of the vector focus. The Laboratório e Serviço de Referência em Esquistossomose (LASERE) of the Centro de Pesquisas Aggeu Magalhães (CPqAM), of the Fundação Oswaldo Cruz (FIOCRUZ), has been conducting systematic surveys along the coast of Pernambuco. These surveys have detected snails infected with $S$. mansoni at rates

Corresponding author: Dra. Verônica Santos Barbosa. Depto. de Parasitologia/ CPqAM/FIOCRUZ. Av. Prof. Moraes Rego s/n, Campus da UFPE, Cidade Universitária, 50740-465 Recife, Pernambuco, Brasil.

Phone: 5581 2101-2661

e-mail: sbveronica85@hotmail.com

Received 10 March 2015

Accepted 25 May 2015 of up to $31 \%$, along with human communities exhibiting severe infection with this parasite ${ }^{(3)(5)(8)(9)(10)(11)(12)}$. In an expedition in September 2013 ${ }^{(13)}$, the first report of the presence of a breeding site for B. glabrata was registered in Serrambi, in the coastal tourist locality of Ipojuca; during this time, 49 specimens were collected. All these specimens were negative for S. mansoni. Attention was drawn to this finding because of the close proximity of Serrambi to Porto de Galinhas, where 425 humans had been diagnosed with schistosomiasis in 2010 .

From October 2013 until the present time, the laboratory has been collecting vector snails on a monthly basis from Serrambi. In September 2014, B. glabrata snails infected with S. mansoni were detected for the first time in Serrambi. In 2014, LASERE began a parasitological survey and registered 2,574 people living there. Of these, 1,414 (54.9\%) underwent feces examination, and $63(4.5 \%)$ were diagnosed with $S$. mansoni infection, with parasite loads between 12 and 2,124 eggs per gram of feces. Until that time, seven breeding sites each for $B$. straminea and B. glabrata were identified in Serrambi. In two of the breeding sites, the snails were shedding cercariae of $S$. mansoni since September 2014, and this finding indicated the start and spread of schistosomiasis transmission in Serrambi (Figure 1).

The results from the 2014 parasitological survey showed that men between the ages of 20 and 39 years were the most frequently parasitized both by $S$. mansoni and other helminthiases (Table 1).

The infected humans could not be considered to be autochthonous because they had been exposed to contaminated waters from endemic areas. Nonetheless, the presence of parasitized B. glabrata snails that were shedding cercariae of 


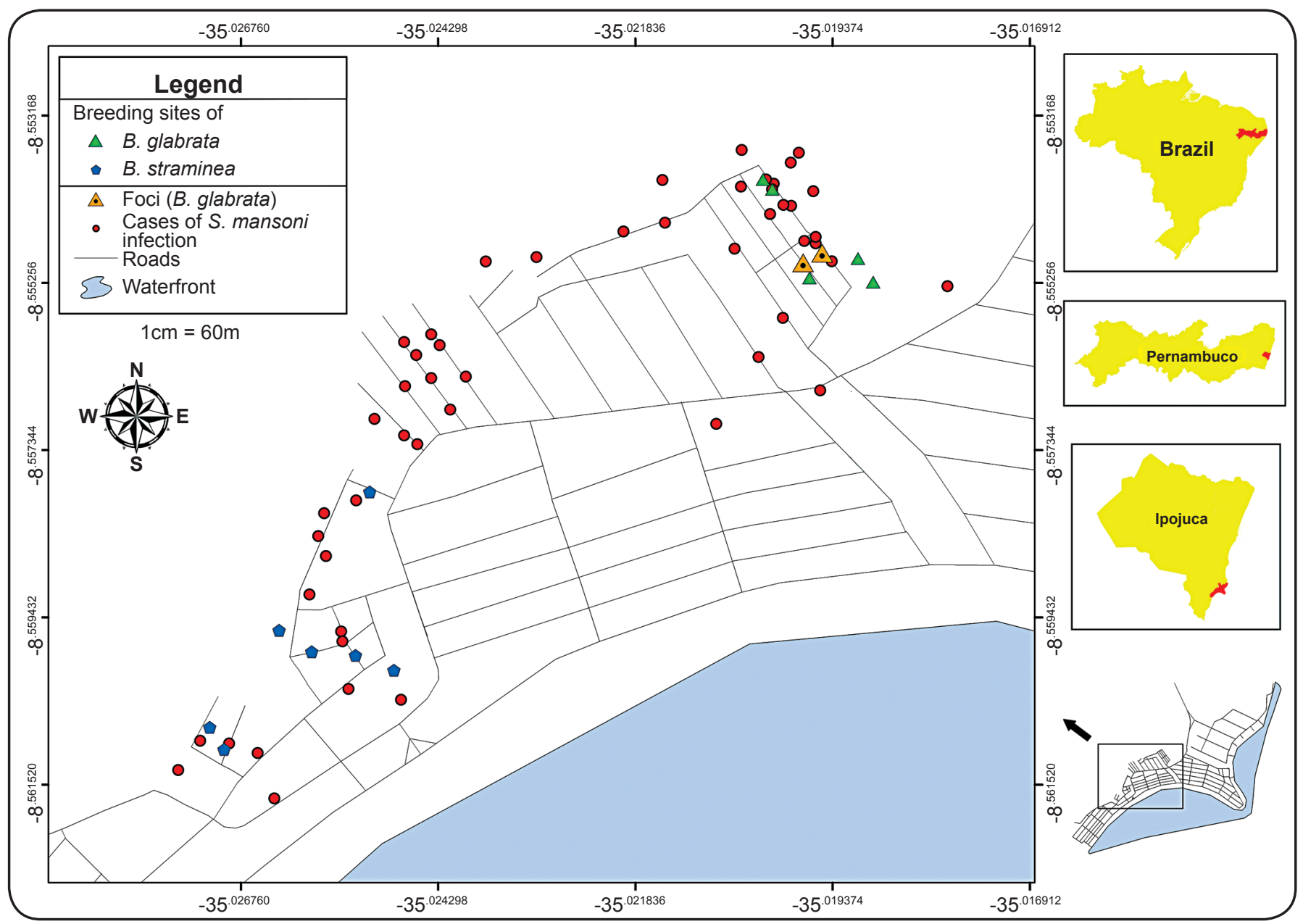

FIGURE 1 - Spatial distribution of the patients diagnosed with schistosomiasis, breeding sites for $B$. glabrata and $B$. straminea, and foci of B. glabrata with snails positive for $\boldsymbol{S}$. mansoni in Serrambi, Ipojuca, State of Pernambuco. B.: Biomphalaria; S.: Schistosoma.

TABLE 1 - Individuals infected with helminths according to sex and age group in Serrambi, Ipojuca, State of Pernambuco.

\begin{tabular}{|c|c|c|c|c|c|c|c|c|}
\hline \multirow[t]{2}{*}{ Variable } & \multicolumn{2}{|c|}{$\begin{array}{c}\text { Schistosoma mansoni } \\
(\mathrm{n}=63)\end{array}$} & \multicolumn{2}{|c|}{$\begin{array}{l}\text { Ascaris lumbricoides } \\
\qquad(\mathrm{n}=38)\end{array}$} & \multicolumn{2}{|c|}{$\begin{array}{l}\text { Trichuris trichiura } \\
\quad(\mathrm{n}=68)\end{array}$} & \multicolumn{2}{|c|}{$\begin{array}{l}\text { Hookworms } \\
\quad(n=25)\end{array}$} \\
\hline & n & $\%$ & n & $\%$ & n & $\%$ & n & $\%$ \\
\hline male & 42 & 66.7 & 20 & 52.6 & 34 & 50.0 & 17 & 68.0 \\
\hline female & 21 & 33.3 & 18 & 47.4 & 34 & 50.0 & 8 & 32.0 \\
\hline $0-9$ & 1 & 1.6 & 16 & 42.1 & 18 & 26.4 & 1 & 4.0 \\
\hline $10-19$ & 8 & 12.7 & 10 & 26.3 & 28 & 41.2 & 6 & 24.0 \\
\hline $20-39$ & 31 & 49.2 & 2 & 5.3 & 11 & 16.2 & 8 & 32.0 \\
\hline $40-59$ & 16 & 25.4 & 9 & 23.7 & 8 & 11.8 & 8 & 32.0 \\
\hline$>60$ & 5 & 7.9 & 1 & 2.6 & 3 & 4.4 & 2 & 8.0 \\
\hline
\end{tabular}


Schistosoma mansoni is an epidemiological indicator suggesting the establishment of disease transmission in Serrambi.

In Serrambi, malacological surveys, involving monthly measurements of environmental and biological data such as rainfall rates, snail population densities, and snail infectivity rates, are ongoing in order to compile seasonal maps for identifying the periods of greater risk of schistosomiasis transmission in this locality.

The diagnosed human patients were properly treated, and the maps containing the malacological information were submitted to the local health department so that preventive measures could be implemented to avoid the establishment of schistosomiasis transmission in another tourist locality in Pernambuco, which would increased the risk of infection for vacationers and tourists who visit this region to admire its natural beauty.

\section{ACKNOWLEDGMENTS}

We thank the technicians of the Laboratório e Serviço de Referência em Esquistossomose (LASERE) of the Centro de Pesquisas Aggeu Magalhães (CPqAM), of the Fundação Oswaldo Cruz (FIOCRUZ), for their support during the field and laboratory studies. We are grateful to the Health Department of Ipojuca for allowing us to conduct this project.

\section{CONFLICT OF INTEREST}

The authors declare that there is no conflict of interest.

\section{REFERENCES}

1. Gonçalves F, Coutinho A, Santana W, Barbosa CS. Esquistossomose Aguda, de caráter episódico, na Ilha de Itamaracá, Estado de Pernambuco. Cad Saude Publica 1991; 7:424-425.
2. Barbosa CS, Domingues ALC, Abath F, Montenegro SML, Guida U, Carneiro J, et al. Epidemia de esquistossomose aguda na praia de Porto de Galinhas, Pernambuco, Brasil. Cad Saude Publica 2001; 17:725-728.

3. Barbosa CS, Araújo KC, Sevilla MAA, Melo F, Gomes ECS, SouzaSantos R. Current epidemiological status of schistosomiasis in the state of Pernambuco, Brazil. Mem Inst Oswaldo Cruz 2010; 105:549-554.

4. Araújo KCGM, Resendes APC, Souza-Santos R, Silveira-Junior JC, Barbosa CS. Análise Espacial dos Focos de Biomphalaria glabrata e de casos humanos de esquistossomose em Porto de Galinhas, Pernambuco, Brasil, no ano de 2000. Cad Saude Publica 2007; 23:409-417.

5. Gomes ECS, Leal Neto OB, Albuquerque J, Silva HP, Barbosa CS. Schistosomiasis transmission and environmental change: a spatiotemporal analysis in Porto de Galinhas, Pernambuco - Brazil. Int J Health Geogr 2012; 11:51.

6. Souza MAA, Barbosa VS, Albuquerque JO, Bocanegra S, SouzaSantos R, Paredes H, et al. Aspectos ecológicos e levantamento malacológico para identificação de áreas de risco para a transmissão da esquistossomose no litoral norte de Pernambuco, Brasil. Iheringia Ser Zool 2010; 100:1-6.

7. Paredes H, Souza-Santos R, Resendes APC, Souza MAA, Albuquerque J, Bocanegra S, et al. Spatial pattern, water use and risk levels associated with the transmission of schistosomiasis on the north coast of Pernambuco, Brazil. Cad Saude Publica 2010; 26:1013-1023.

8. Souza MAA, Barbosa VS, Wanderlei TNG, Barbosa CS. Criadouros de Biomphalaria, temporários e permanentes, em Jaboatão dos Guararapes, PE. Rev Soc Bras Med Trop 2008; 41:252-256.

9. Barbosa CS, Gonçalves JF, Albuquerque J, Barbosa FS. Urban Schistosomiasis in Itamaracá Island, Pernambuco, Brazil: Epidemiological Factors Involved in the Recent Endemic Process. Mem Inst Oswaldo Cruz 1998; 93:265-266.

10. Barbosa CS, Pieri OS, Silva CB, Barbosa FS. Ecoepidemiologia da esquistossomose urbana na ilha de Itamaracá, Estado de Pernambuco. Rev Saude Publica 2000; 34:337-341.

11. Barbosa CS, Araújo KC, Antunes L, Favre T, Piori OS. Spatial Distribution of Schistosomiasis Foci on Itamaracá Island, Pernambuco, Brazil. Mem Inst Oswaldo Cruz 2004; 99:79-83.

12. Gomes ECS, Leal Neto OB, Oliveira FJ, Campos JV, Souza-Santos R, Barbosa CS. Risk analysis for occurrences of schistosomiasis in the coastal area of Porto de Galinhas, Pernambuco, Brazil. BMC Infect Dis 2014; 14:101.

13. Barbosa CS, Souza-Santos R, Gomes ECS, Araújo K, Albuquerque J, Melo F, et al. Epidemiologia da Esquistossomose no Litoral de Pernambuco. Rev Patol Trop 2014; 43:436-445. 